\title{
Assessment of the Basic Law Lesson Consistent with the Opinions of Social Studies Pre-Service Teachers
}

\author{
Sibel Oğuz Haçat ${ }^{1}$ \\ ${ }^{1}$ Kastamonu University, Faculty of Education, Department of Social Studies, Kastamonu/Turkey \\ Correspondence: Sibel Oğuz Haçat, Kastamonu University, Faculty of Education, Department of Social Studies, \\ Kastamonu/Turkey
}

Received: December 23, 2017

Accepted: January 29, 2018

Online Published: January 31, 2018

doi:10.5430/ijhe.v7n1p103

URL: https://doi.org/10.5430/ijhe.v7n1p103

\begin{abstract}
The aim of the present study is to identify the approach of social studies pre-service teachers to legal topics in the "Basic Law" lesson within the Social Studies Teaching Bachelor's Degree Program. A case study based on qualitative research methods was employed. The study group consisted of 57 social studies pre-service teachers. Data was obtained using semi-structured interview forms consisting of open-ended questions. The interview form was administered twice, at the beginning and at the end of the semester. Data obtained was analysed using content analysis. At the beginning of the semester, the motives for teaching of the Basic Law lesson were identified in seven different categories. Consistent with the opinions of the pre-service teachers, it was determined that these categories were related to 26 subcategories. However, the motives for teaching the Basic Law lesson were indicated in 10 different categories at the end of the semester. Consistent with the opinions of the pre-service teachers, it was determined that the latter categories were related to 29 subcategories. In conclusion, it was demonstrated that the content of the lesson influenced students' opinions. Based on the results of the study and the literature review, there are a limited number of studies that focus on the teaching of legal topics in social studies education in our country. Thus, in the future, further studies should be carried out in this field.
\end{abstract}

Keywords: Basic law, Social studies, Social studies pre-service teacher

\section{Introduction}

Following an investigation of the Social Studies Teaching Department, a teacher training bachelor's degree program under the Faculty of Education, it was determined that the content of the Basic Law lesson includes fundamental legal concepts, social order and the rules of law, legal phenomena and legal operations, the judicial system, the historical development of the Turkish legal system and its current structure, and relationships between education and law (YÖK, 2007). The aim of teaching fundamental legal concepts is to help students understand the operation of law. The lessons generally involve concepts such as laws, the relationship between laws and values, justice, freedom, equality, ownership, and power. Additionally, the explanation of concrete documents, such as the Constitution and the Bill of Human Rights, facilitates the understanding of legal topics. Instruction pertaining to authorities that comprise the legal system, such as law enforcement officers, lawyers, and judges, is within the scope of this lesson. Issues related to understanding why rules and laws are necessary, how rules protect people, and what can be done in the case of an injustice are covered in these lessons (Savage \& Armstrong, 2000). Ensuring the protection of the property rights of individuals, providing information about the judicial system and the roles and responsibilities of representatives in the judicial system, providing examples of the rights and freedoms guaranteed under the Constitution, as well as the prevention of alienation from law among students, are also covered in the lessons (Gargia \& Michaels, 2001).

Today, 'social studies' that involves topics from social sciences and is simplified and revised (Dönmez, 2003) brings to mind a lesson that encompasses an independent area relevant to any branch of social sciences - history, geography, psychology, economics, anthropology, politics, law etc. (Akdağ, 2009) — and covers more concrete subjects that fit the level of students in primary education and are more closely related to their lives (Akbaşl1, 2009). Each of these branches investigates the human phenomenon. They differ, however, regarding the dimension they address in this phenomenon. For example, the discipline of Law addresses human rights and freedoms, as well as relevant laws (Tay, 2011). Furthermore, Judicial Science covers fundamental information and concepts that students encounter and use in daily life. 
Law is a system of rules regulating the relationships among people and between people and society, established for the purpose of ensuring the welfare of society or individuals and reinforced with public power (Gözübüyük, 2009; Aslan, Kortunay, Şenyüz \& Deliveli, 2011; Güriz, 2012; Bilge, 2012; Gözler, 2016). At the same time, law represents a set of rules that maintain order in a society that seeks justice in order to ensure the common welfare of the society, and these rules are reinforced through government power (Atay, 2016). Education pertaining to law, which has been assigned a place in social studies curricula (Patrick and Hoge, 1991) since 1975, aims to ensure socialization, to regulate the relationships among people and between people and society, and to teach the legal rules that draw their strength from government authority (Oğuz, 2013).

There are two main aspects that differentiate social studies as a field of investigation: social studies designed to raise good citizens, and social studies as an integrative discipline that involves several fields of science (Demirkaya, 2006). A good citizen refers to an individual who fulfils civic duties, knows his or her rights and takes legal action when needed, is open to improvement while adhering to fundamental values, shows a pacifist approach within his environment, develops a sense of responsibility, obeys the rules and warns those who fail to obey them, and exercises his or her rights and freedoms, including the right to education, the right to vote, etc. (Oğuz, 2013). It is essential that social studies teachers who deliver this lesson, which involves several branches of science, receive a strong education in history, philosophy, anthropology, sociology, social psychology, law, geography, and economics (Duran, 2011). Yazicı and Erdilmen (2011) indicate that legal concepts involve technical terms, and thus, social sciences teachers who provide this lesson must possess knowledge of Basic Law concepts. Toward this end, Basic Law education is given a place in the social studies teaching program. In conclusion, it is important for social studies pre-service teachers to have information about legal topics that complement social studies that strives to raise good citizens. With the teaching of social studies, teachers are expected to instil in students a philosophy of life. In other words, they assume the responsibility of teaching students the information, attitude, skills and concepts that will make them good citizens as they enter into adulthood (Oğuz, 2013). Undoubtedly, the inclusion of the legal issues in the Social Studies Teaching Program obliges the social science teacher candidates to learn the basic concepts of law. In this sense, basic law courses are included in the Social Studies education undergraduate program in order to make the teaching of legal subjects better, to guide teacher candidates, and to minimize the problems that may be encountered in practice. However, when the relevant literature is searched, it is seen that comprehensive and detailed studies about basic legal issues of social science teacher candidates have not been done. Therefore, it is believed that the social science teacher candidates' scientific determination of the basic legal issues will contribute to the elimination of deficiencies in this field and will be the source of future work. In light of this, the aim of the present study is to demonstrate the approaches of social studies pre-service teachers to legal topics within the scope of the "Basic Law" lesson taught in the Social Studies Teaching Bachelor's Degree Program.

\section{Method}

The present study seeks to uncover the opinions of pre-service teachers regarding the Basic Law lesson. For this purpose, a case study based on qualitative research methods was employed. The case study is a research method that is based on "how" and "why" questions, allowing for the investigation of a phenomenon or a fact in greater detail (Yıldırım \& Şimşek, 2016). The study group consists of 57 second-year-students studying to complete the Social Sciences Teaching Program through the Faculty of Education at the University of Kastamonu during the fall 2016-2017 semester. The students were selected using homogeneous sampling from purposive sampling methods. Homogeneous sampling refers to carrying out a study in a homogenous sub-group/situation selected in line with the subject of study out of the entire population (Büyüköztürk et al., 2012). Accordingly, semi-structured interview forms consisting of open-ended questions developed by the researcher were used for data collection. The data collection tool refers to the means that allow for the identification of the opinions of people, as well as their feelings, attitudes and the factors that influence their behaviour (Ekiz, 2009). The validity and reliability of the study was ensured with written quotes taken directly from the data provided by students. The written documents obtained were analysed through content analysis. The opinions of students were directly quoted. In the analysis of the data, pre-service teachers were given the following codes: M1 (Male participant 1); F1 (Female participant 1)

\section{Findings}

The findings pertaining to the opinions of second-year social studies pre-service teachers regarding the Basic Law lesson, as well as the findings about the motives for teaching the Basic Law lesson to social studies pre-service teachers, are provided below: 
Table 1. Opinions of social studies pre-service teachers at the beginning of the semester regarding the motives for teaching the Basic Law lesson.

\begin{tabular}{|c|c|c|c|}
\hline \multirow{3}{*}{$\begin{array}{l}\text { Categories regarding the } \\
\text { motives for teaching the Basic } \\
\text { Law lesson }\end{array}$} & \multirow{3}{*}{$\begin{array}{l}\text { Subcategories regarding the motives for teaching } \\
\text { the Basic Law lesson to social studies pre-service } \\
\text { teachers }\end{array}$} & \multicolumn{2}{|l|}{ Gender } \\
\hline & & Female & Male \\
\hline & & $\bar{f}$ & $f$ \\
\hline Enforcement of the rules of law & $\begin{array}{l}\text { Raising conscious individuals } \\
\text { (F16,M5,F21,F36,M17), Teaching individual rights } \\
\text { and responsibilities in social life (F15,M20,M14), } \\
\text { Teaching community life, (M1,M4,M10), Teaching } \\
\text { the enforcement of the rules of law (F8,F14,F22) }\end{array}$ & 7 & 7 \\
\hline Fundamental rights and duties & $\begin{array}{l}\text { Teaching the rules in community life } \\
\text { (F1,F6,F10,F29,F8,F13,M18), Providing } \\
\text { information about rights that can be exercised in } \\
\text { case of difficulty (M6,M9,F23,F35), Teaching the } \\
\text { rules of community life (M10), The importance of } \\
\text { knowing one's own rights (F3), Teaching students } \\
\text { their rights and freedoms (M4, } \\
\text { M5,F15,F17,F18,F19,F20,F21,M9,F22,M13,M16,F } \\
27, \mathrm{~F} 28, \mathrm{~F} 36), \text { Avoiding the violation of individual } \\
\text { rights (F15), Raising individuals who defend their } \\
\text { rights (M15,M16), Creating awareness about rights } \\
\text { (M17) }\end{array}$ & 19 & 11 \\
\hline Effects on human life & $\begin{array}{l}\text { The teacher's role in applying rules (F3,M5), The } \\
\text { strong relevance of social studies lessons to real life } \\
\text { (F5, F8, F9), The effect of the rules of law on } \\
\text { professional life }(\mathrm{F} 7, \mathrm{~F} 14)\end{array}$ & 6 & 1 \\
\hline Effects on social order & $\begin{array}{l}\text { Inclusion of all social phenomena and cases in } \\
\text { society (F13,F20,F31,F 32), Providing information } \\
\text { about society (F13,M9,F33), Explaining daily life } \\
\text { situations (M4,M7,F29) }\end{array}$ & 7 & 3 \\
\hline Justice & $\begin{array}{l}\text { Being fair in social life (F2), Teaching injustices } \\
\text { (M3,M11), Ensuring the investigation of justice } \\
\text { (F12) }\end{array}$ & 2 & 2 \\
\hline Citizenship knowledge & $\begin{array}{l}\text { Teaching citizenship and human rights } \\
\text { (F4,F11,F30), Providing information about legal } \\
\text { topics (E3,E8,F22,F24,F25,E12,F26,F34), Raising } \\
\text { good citizens (M11,M12,F28,F31) }\end{array}$ & 10 & 5 \\
\hline Learning about the Constitution & $\begin{array}{l}\text { Teaching the Constitution (M18), The effect of the } \\
\text { Constitution on human life (M21) }\end{array}$ & & 2 \\
\hline
\end{tabular}

When Table 1 is examined, it can be seen that the motives for teaching the Basic Law lesson are listed under seven categories at the beginning of the semester. Consistent with the opinions of pre-service teachers, it is determined that these categories are relevant to 26 subcategories. These seven categories are Enforcement of the rules of law, Teaching rights and responsibilities, Effects on human life, Effects on social order, Justice, Citizenship knowledge, and Learning about the Constitution. Within the framework of these motives, social studies pre-service teachers expressed the importance of taking this lesson. Among these seven primary motives, Teaching rights and responsibilities was the most common category, while Learning about the Constitution was the least common category.

"Basic Law is important for individuals in terms of learning the rules in community life. A pre-service teacher who takes this lesson can try to inform his/her students about the rules in community life when he/she teaches the lesson." $(F 2)$ 
"Rights and the rules of law are among the fundamental information that a teacher can give to his/her students. Since social studies teachers specifically teach about social life, it is essential that they have a good command of this subject." (F3)

"When we graduate, we will take lessons on citizenships and human rights. These lessons are based on Basic Law." (F4)

“The Basic Law lesson teaches us justice, injustice and truth.” (F5)

"In my opinion, knowledge of Basic Law is necessary in social studies. So, learning fundamental information about law will be useful both for pre-service teachers and the people in their environment." (M3)

"Law is essential for life. A teacher is the continuation of education and the future. A social studies teacher teaches students the present day, all of the realities of the current situation, injustice, equality, as well as all the rules that are necessary for the continuation of life." (F10)

"A social studies lesson helps children at the secondary school age who are not yet conscious about their rights to learn about their rights.” (M4)

"I believe that it is necessary to learn our rights and responsibilities in social life and pass this knowledge on to our students.” (F15)

"When an individual knows the fundamental rules of law, he can defend himself and claim his rights. As teachers guide students with their knowledge, their students will be conscious of their rights and freedoms." (M5)

"Law should not be handled as a simple concept. It covers equality, individual rights and freedoms. It is essential that social studies teachers know this well so that they can teach concepts like equality, rights and freedoms, and responsibilities to future generations.” (F19)

"We take the Basic Law lesson in order to protect the rights we are born with, defend ourselves before the law, and raise conscious individuals who are aware of their rights.” (F21)

"I believe that this lesson should be taught, as it is under the field of social studies. As the name implies, this lesson is necessary for learning the rights and freedoms in a society." (F22).

"Social studies teachers aim to raise good and quality citizens in a country. They want their students to become useful in their environment and serve their country well. If law means justice and is essential for everybody, it should be included in social studies education." (M11)

"The Basic Law lesson is given in the Social Studies Teaching program to teach the rules we have in our country and the Constitution. With this lesson, students do not merely learn the Constitution, but also how to apply its provisions." (M18)

"We have to become good citizens before we become good teachers. For this, it is vital to learn laws and regulations.” (F31)

"The teaching of Basic Law under the Social Studies Teaching Program helps pre-service teachers think in a broader way, keeps them informed about current issues in the agenda of our country, and helps them feel free to express their opinion." (F32) 
Table 2. Opinions of social studies pre-service teachers at the end of the semester regarding the motives for teaching the Basic Law lesson

\begin{tabular}{|c|c|c|c|}
\hline \multirow{3}{*}{$\begin{array}{l}\text { Categories regarding the } \\
\text { motives for teaching the Basic } \\
\text { Law lesson }\end{array}$} & \multirow{3}{*}{$\begin{array}{l}\text { Subcategories regarding the motives for teaching } \\
\text { the Basic Law lesson to social studies pre-service } \\
\text { teachers }\end{array}$} & \multicolumn{2}{|l|}{ Gender } \\
\hline & & Female & Male \\
\hline & & $\bar{f}$ & $f$ \\
\hline $\begin{array}{l}\text { Learning about the judicial } \\
\text { system }\end{array}$ & $\begin{array}{l}\text { Knowing about the historical development of the } \\
\text { judicial system (M2), Knowing about the branches } \\
\text { of the judicial system (M1) }\end{array}$ & & 2 \\
\hline $\begin{array}{l}\text { Fundamental rights } \\
\text { responsibilities }\end{array}$ & $\begin{array}{l}\text { Learning one's own rights } \\
\text { (M2,F10,F1,F3,F10,F12,F13,M4,M15,M17,F31), } \\
\text { Knowing how to claim one's rights (M5,F15,F34), } \\
\text { Knowing about rights and freedoms } \\
\text { (F17,M7,F18,F22,F24,F29,F33,F36), Being aware } \\
\text { of fundamental rights (F21,F28,F34), Knowing } \\
\text { one's responsibilities (M9,M10,F28,F35,F36) }\end{array}$ & 22 & 8 \\
\hline $\begin{array}{l}\text { The relationship between } \\
\text { citizens and the government }\end{array}$ & $\begin{array}{l}\text { Learning about the government-citizen relationship } \\
\text { (F2,F9), Raising conscious citizens (F3,F15) }\end{array}$ & 4 & \\
\hline Rules of social order & $\begin{array}{l}\text { Target of raising good citizens } \\
\text { (F5,F13,F14,F16,F17,F19,M9,F25,M12,F27,F28,F } \\
\text { 29,F30,F33,F36), Learning the rules that regulate } \\
\text { social life (M2,F7,M10,M12,M13,F26), Knowing } \\
\text { citizenship duties (M6,F18,M18), Knowing the } \\
\text { rules of law (F32,M20) }\end{array}$ & 17 & 9 \\
\hline Justice & Teaching of justice (F5) & 1 & \\
\hline $\begin{array}{l}\text { Learning about the resources of } \\
\text { law }\end{array}$ & $\begin{array}{lr}\text { Learning } & \text { legal } \\
(\mathrm{F} 6, \mathrm{M} 10, \mathrm{~F} 25, \mathrm{~F} 27, \mathrm{~F} 30, \mathrm{M} 18, \mathrm{M} 19, \mathrm{M} 20), & \text { Knowics } \\
\text { the resources of law }(\mathrm{F} 5, \mathrm{~F} 11) & \end{array}$ & 6 & 4 \\
\hline Learning about the Constitution & $\begin{array}{l}\text { Learning about the Constitution (F7,F10,F12,F14, } \\
\text { M6,M8,F18,F20,M16,F30), The importance of the } \\
\text { Constitution (F9) }\end{array}$ & 8 & 2 \\
\hline Being aware of current issues & $\begin{array}{l}\text { Examining current issues from another perspective } \\
\text { (F1,F20,M15,M16,F28), Following current issues } \\
\text { (M19), Analysis of current issues according to the } \\
\text { rules of law (F32,F11,F12,F21), Being aware of } \\
\text { current issues (F16,F35,F36), Learning about daily } \\
\text { life (F6,F8,E4,F22,F14) }\end{array}$ & 14 & 4 \\
\hline Teaching of law & $\begin{array}{l}\text { The responsibility of social studies teachers to teach } \\
\text { legal topics (M3,F11,F12,M7,M8,F21,M13,M14, } \\
\text { F26,M16,M20,M21), Using professional } \\
\text { experiences (F23), Compensating for lack of } \\
\text { information about general culture (M11,F34), } \\
\text { Inclusion in social studies educational curriculum } \\
\text { (F31,M20,F36) }\end{array}$ & 8 & 10 \\
\hline Learning About state bodies & $\begin{array}{l}\text { Learning about state mechanisms } \\
\text { (M1,F5,F15,M8,F18,F19,F20,M9,F30), Learning } \\
\text { about the functioning of the state (F30,M18) }\end{array}$ & 7 & 4 \\
\hline
\end{tabular}

Table 2 lists 10 different categories regarding the motives for teaching the Basic Law lesson. It is determined that these categories are related to 29 subcategories, consistent with the opinions of social studies pre-service teachers. The primary categories are Learning about the judicial system, Fundamental rights and responsibilities, The relationship between citizens and the government, Rules of social order, Justice, Learning the resources of law, 
Learning about the constitution, Being aware of current issues, Teaching of law, and Learning about state bodies. Within the scope of these motives, pre-service social studies teachers pointed to the importance of this lesson. The most common category among the pre-service social studies teachers was Fundamental rights and responsibilities, while Justice was the least common category.

Opinions of pre-service social studies teachers regarding the Basic Law lesson:

"The Basic Law lesson is definitely necessary, because I learned how the government mechanism functioned after I began to take this lesson." (M1)

"The Basic Law lesson is necessary for pre-service social studies teachers, because I learned the rights and freedoms of individuals in society, the regulation of the relationship between the government and the people, as well as how to become a good citizen when I took this lesson." (F2)

"It is definitely a lesson that every citizen needs, because the violation of the rules of law and the wrong practices that result due to not being aware of our own rights will be eliminated when teachers have knowledge of Basic Law and pass this knowledge on to their students." (F3)

"With the Basic Law lesson, I learned the historical development of the Turkish judicial system and legal requisites. This lesson is necessary for pre-service social studies teachers, because we are the ones who will teach students how to protect their rights." (M2).

"This is one of the fundamental lessons that pre-service social studies teachers should take in order to raise good citizens in the future. This is because it is the duty of social studies teachers to teach students how to defend themselves in the future." (F13)

"Social studies teachers are supposed to have knowledge about the Constitution. They should have an idea about what might happen in the country or to individuals." (F14)

"With the Basic Law lesson, we learned how our Constitution, laws and the judicial system functioned. This lesson is also relevant to our field as the situations that we see in daily life are closely associated with the situations in our social relations." (K15)

"In this lesson, I learn what to do when I encounter a problem in social life, to interpret current issues better, as well as how to defend my rights. I believe I will be teaching these to my students in the future." (M5)

"In this lesson, I became aware of the necessity of learning the rights and freedoms I have in the case of problems that can emerge with relevance to my profession. This lesson is definitely necessary in order to have background information about the lessons that we, social studies teachers, will teach our students in the future." (F18)

"In the Basic Law lesson, we learn the qualities of a good citizen as well as the concepts and duties of the President, Members of Parliament, etc. After all, social studies teachers are responsible for raising good citizens, which is the main reason for the importance of this lesson." (F19)

"I need this lesson in order to be able to teach my students their rights and freedoms in the future." (F20)

"Thanks to the Basic Law lesson, I learned to analyse current issues better. I learned the real meanings of frequently-used legal terms, as well as how to use the rights that I have. I also learned in what ways I can resolve a legal problem. When I become a social studies teacher, I need to teach the same to my students." (F21)

"Since social studies is a blended form of different sciences and covers subjects from almost any branch of science, we all need to take this lesson." (M11)

"This lesson is important in terms of learning our rights and responsibilities, as well as passing them on to future generations. It is crucial for raising conscious citizens." (F28)

"Besides theoretical information, we are supposed to teach our students what methods of resolution they can take in the case of a real-life problem. The Basic Law lesson is important for social studies teachers, as it gives us the opportunity to improve ourselves and our horizons." (F34)

"The Basic Law lesson is definitely necessary for us, because we have learned a lot about the current issues and the Constitution in this lesson. This information will be useful in the future, both in our daily lives and our professions." (M16)

"If pre-service teachers do not have sufficient legal knowledge when they start their profession, they can't take the necessary action in the case of a legal problem. The Basic Law lesson is a useful lesson for pre-service teachers. In fact, I believe it should be given in all majors, not just in social sciences. " (F23) 


\section{Conclusion and Discussion}

When the literature on legal topics and their teaching within the scope of a social studies lesson was examined, it was determined that previous studies focused primarily on the placement and the importance of legal topics in the curriculum of the social studies teaching program, and the opinions of secondary school students and pre-service teachers regarding legal topics were given weight (Wagner, 2007; Oğuz, 2013a; Oğuz, 2013b; Gökdemir, 2013; Sabanc1, 2014; Kara, 2017; Kara \& Tangülü, 2017). However, social studies teacher candidates did not have a study on the basic law taught theoretically. The present study focuses on the motives of pre-service social studies teachers in taking the "Basic Law" lesson as part of the curriculum of the social studies teaching program, as well as their opinions about the importance of this lesson.

Within the scope of the study, it was determined that the categories of Fundamental rights and duties, Justice, and Learning about the Constitution were among the motives for taking the Basic Law lesson identified at the beginning as well as the end of the semester. Except for the category of Justice, subcategories relevant to the primary categories were mentioned by more participants at the end of the semester. It was also found that a greater number of categories was identified at the end of the semester. These included the following: Rules of social order, Learning about the judicial system, The relationship between citizens and the government, Learning about state bodies, Teaching of Law, and Learning about the Constitution. The pre-service teachers also shared their opinions about Being aware of current issues, Following current issues, Analysing current issues according to the rules of law, and Learning more about daily life. Furthermore, they indicated that social studies teachers had a responsibility to teach certain topics of law. In this regard, it can be said that the structure of the Basic Law lesson increased the awareness of pre-service social studies teachers regarding this lesson. Similarly, Wagner (2007) investigated the influence of educators in unveiling the perceptions of legal literacy and in teacher formation programs. In their study, Kara and Tangülü (2017) indicated that there were topics relevant to the discipline of law in terms of general aims, concepts, values and gains in the 2005 Social Studies Teaching Curriculum, but they were not given a place under 'skills'. They also indicated that one of the most important functions of a social studies lesson is to help students gain legal literacy. On the other hand, Oğuz (2013) pointed out that legal topics were given a place in the skills dimension of the 2005 Social Studies Teaching Program. Furthermore, it was concluded that secondary school students demonstrated an average level of achievement in a test on legal knowledge, whereas they demonstrated an advanced level of achievement on a legal literacy scale.

Pre-service social studies teachers who are expected to teach subjects about citizenship, human rights, and legal issues pointed to the importance of this lesson at the beginning of the semester. At the end of the semester, they also indicated that legal subjects should be included in social studies teaching curricula, as they are useful in compensating for the lack of general cultural knowledge. They also stated that they could benefit from their own knowledge of the rules of law in their professional lives. Similarly, Gökdemir (2013) argues in his study that legal topics have been given a place in social studies teaching curricula since 1924, up to the present day. Based on the findings from this study, it is clear that legal topics should be accorded more significant placement in social studies curricula in the future. Kara (2016) pointed to the similarities between the disciplines of law and social studies in terms of facilitating improvements in the lives of individuals, indicating that there is a relationship between the two disciplines, as social studies actively benefits from juridical science. In addition to the theoretical teaching of the Basic Law lesson, current issues can be given greater weight so that students gain a better understanding of fundamental legal topics. Based on the results from the study and the literature review, there are a limited number of studies that focus on the teaching of legal topics in social studies education in our country. Thus, in the future, further studies should be carried out in this field.

\section{References}

Akbaşlı, S. (2009). Sosyal Bilgiler Öğretiminde Vatandaşlık ve İnsan Hakları Eğitimi. R. Turan, A. M. Sünbül, H. Akdağ. (Edt.). Sosyal Bilgiler Öğretiminde Yeni Yaklaşımlar-1 (pp. 41-85). Ankara: Pegem Akademi.

Akdağ, H. (2009). ‘Sosyal Bilgilerin Tanımı, Amacı, Önemi ve Türkiye'deki Yeri. R. Turan, A. M. Sünbül, H. Akdağ. (Edt.). Sosyal Bilgiler Öğretiminde Yeni Yaklaşımlar-1 (pp.1-25). Ankara: Pegem Akademi.

Aslan, Y. İ. , Şenyüz, D. , Kortunay, A. ve Deliveli, Ö. (2009). Hukuka giriş. 6. Baskı. Bursa: Ekin Basın Yayın Dağıtım.

Atay, E.E. (2016). Hukuk başlangıcı. 3. Bask1. Ankara: Gazi Kitabevi.

Bilge, N. (2012). Hukuk başlangıcı. Hukukun temel kavramları ve kurumları. 30. Bası. Ankara: Turhan Kitabevi.

Büyüköztürk, Ş. ,Çakmak, K. E. , Akgün, Ö. E. , Karadeniz, Ş. ,Demirel, F. (2012). Bilimsel Araştırma Yöntemleri. 
11. Bask1. Ankara: Pegem Akademi.

Demirkaya, H. (2006). Hayat Bilgisi ve Sosyal Bilgiler Programında İçerik ve Kazandırılacak Beceriler. A. Tanrı̈̆̆en. (Ed.). Hayat Bilgisi ve Sosyal Bilgiler Öğretimi (pp.73-116). İstanbul: Lisans Yayıncılık.

Duran, H. (2011). Sosyal Bilgilerde Sosyolojinin Yeri ve Önemi. R.Turan, K. Ulusoy (Ed.). Sosyal Bilgilerin Temelleri (pp.173-193). 2. Bask1. Ankara: Pegem Akademi.

Dönmez, C. (2003). Sosyal Bilimler ve Sosyal Bilgiler. C. Şahin. (Ed.). Konu Alanı Ders İnceleme Kılavuzu (pp. 31-41). Ankara: Gündüz.

Ekiz, D. (2009). Bilimsel araştırma yöntemleri.2. Baskı. Ankara: Anı yayıncılık.

Gökdemir, A. (2013). 1924'den Günümüze ilköğretim sosyal bilgiler programlarındaki hukuk konularının incelenmesi. (Yayımlanmamış Yüksek Lisans Tezi). Niğde Üniversitesi, Eğitim Bilimleri Enstitüsü: Niğde.

Gözler, K. (2016). Genel hukuk bilgisi. Meslek yüksekokulları için. 16.Baskı. Bursa: Ekin Basın Yayın Dağıtım.

Gözübüyük, Ş. (2009). Hukuka Giriş ve Hukukun Temel Kavramları. 30. Bası. Ankara: Turhan Kitabevi .

Güriz, A. (2012). Hukuk başlangıcı, 14. Baskı. Ankara: Siyasal Kitabevi.

Kara, H. (2017). Sosyal bilgiler öğretmen adaylarının hukuk okuryazarlık düzeylerinin belirlenmesi. (Yayımlanmamış Yüksek Lisans Tezi). Muğla Sıtkı Koçman Üniversitesi, Eğitim Bilimleri Enstitüsü: Muğla.

Kara, H. ve Tangülü, Z. (2017). Sosyal bilgiler öğretim programında hukuk ve politik okuryazarlığı üzerine bir durum incelemesi. Araştırma ve Deneyim Dergisi, 2(1), 1-28. Retrieved from http://dergipark.gov.tr/download/article-file/309508.

Oğuz, S. (2013a). Ortaokul öğrencilerinin sosyal bilgiler eğitimi çerçevesinde hukuk okuryazarlık düzeylerinin belirlenmesi. (Yayımlanmamış Doktora Tezi). Gazi Üniversitesi, Eğitim Bilimleri Enstitüsü: Ankara.

Oğuz, S. (2013b). Hukuk Okuryazarlığı. E. Gençtürk ve K. Karatekin (Ed.), Sosyal Bilgiler için Çoklu Okuryazarlıklar (pp. 160-176). Ankara: Pegem Akademi.

Patrick, J. J. Ve Hoge, J. D. (1991). Teaching Government, Civics, and law, in J.P. Shaver, (Ed). Handbook of Research on Social Studies Teaching and Learning: A project of the National Council for the Social Studies (pp. 400-410). New York: Macmillan.

Sabanc1, o. (2014) Üstkavramsal ögretim etkinliklerinin öğrencilerin sosyal bilgiler dersinde yer alan hukuk konularını anlamaları üzerine etkisi. (Yayımlanmamış Doktora Tezi). Gazi Üniversitesi, Eğitim Bilimleri Enstitüsü: Ankara.

Savage, T.V. \& Armstrong, D.G. (2000). Effective Teaching in Elementary Social Studies. New Jersey: Prentice-Hall Inc.

Tay, B. (2011). Sosyal bilgiler öğretiminin dünü bugünü ve yarını. R. Turan ve R. Ulusoy (Ed). Sosyal bilgilerin temelleri (pp.2-20). Ankara: Pegem Akademi.

Wagner, P. H. (2007). An Evaluation of the Legal Literacy of Educators and the Implications for Teacher Preparation Programs. California: Education Law Association $53^{\text {rd }}$ Annual Conferance, November 16. ED: 499689.

Yazıcı, K ve Erdilmen, Ş. (2011). Sosyal bilgiler öğretiminde hukuk. R. Turan ve R. Ulusoy (Ed). Sosyal bilgilerin temelleri (pp. 273-295). Ankara: Pegem Akademi.

Yıldırım, A. ve Şimşek, H. (2016). Sosyal bilimlerde nitel araştırma yöntemleri. 10.Baskı. Ankara: Seçkin Yayıncilik.

Yükseköğretim Kurulu [YÖK]. (2007). Eğitim fakültesi öğretmen yetiştirme lisans programları.http://www.yok.gov.tr/documents/10279/49665/sosyal_bilgiler.pdf/5b46fcf9-d79c-46dc-a8e5-9b94 4c99ec6a adresinden 01.01.2018 tarihinde indirilmiştir. 